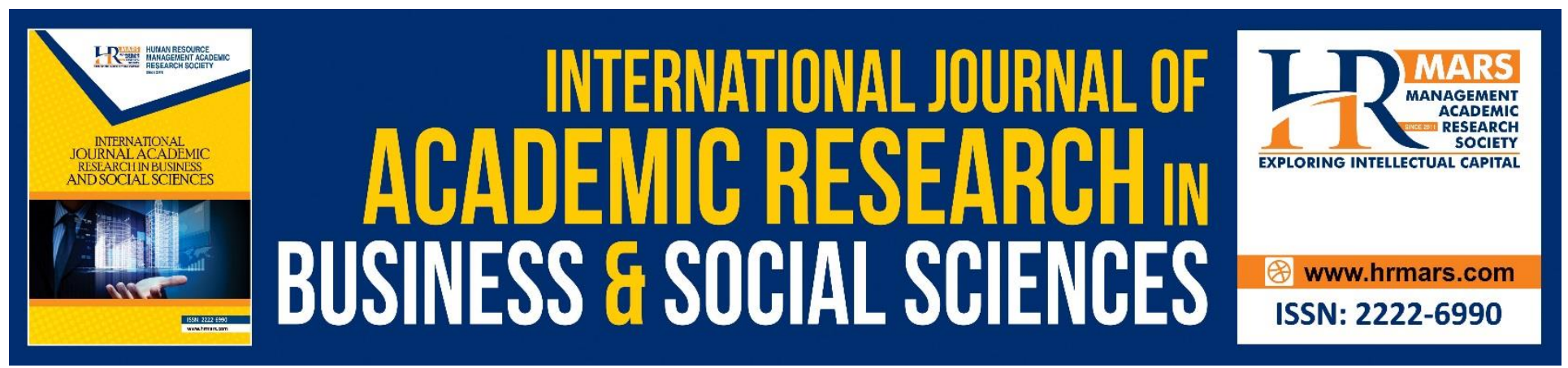

\title{
Development, Validity and Reliability of the Art Drawing House-Tree-Person (AD-HTP) Module among the Counselors in Malaysia
}

Mohammad Aziz Shah Mohamed Arip, Mohd Radhi Abu Shahim, Nurul Syahirah Husin

To Link this Article: http://dx.doi.org/10.6007/IJARBSS/v8-i10/4772

DOI: $10.6007 /$ IJARBSS/v8-i10/4772

Received: 17 Sept 2018, Revised: 26 Oct 2018, Accepted: 27 Oct 2018

Published Online: 31 October 2018

In-Text Citation: (Arip, Shahim, \& Husin, 2018)

To Cite this Article: Arip, M. A. S. M., Shahim, M. R. A., \& Husin, N. S. (2018). Development, Validity and Reliability of the Art Drawing House-Tree-Person (AD-HTP) Module among the Counselors in Malaysia. International Journal of Academic Research in Business and Social Sciences, 8(10), 676-691.

\section{Copyright: (C) 2018 The Author(s)}

Published by Human Resource Management Academic Research Society (www.hrmars.com)

This article is published under the Creative Commons Attribution (CC BY 4.0) license. Anyone may reproduce, distribute, translate and create derivative works of this article (for both commercial and non-commercial purposes), subject to full attribution to the original publication and authors. The full terms of this license may be seen

at: http://creativecommons.org/licences/by/4.0/legalcode

Vol. 8, No. 10, 2018, Pg. 676 - 691

Full Terms \& Conditions of access and use can be found at http://hrmars.com/index.php/pages/detail/publication-ethics 


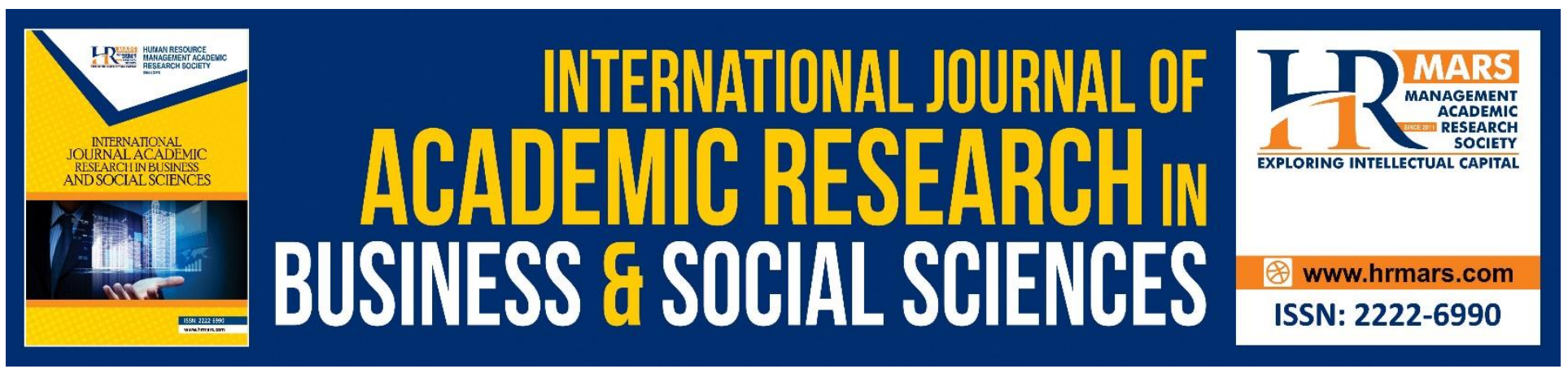

\title{
Development, Validity and Reliability of the Art Drawing House-Tree-Person (AD-HTP) Module among the Counselors in Malaysia
}

\author{
Mohammad Aziz Shah Mohamed Arip \\ Associated Professor, Faculty of Human Development, Sultan Idris Education University, 35900 \\ Tanjong Malim, Perak, Malaysia \\ Email: aziz.shah@fpm.upsi.edu.my
}

\begin{abstract}
Mohd Radhi Abu Shahim
Lecturer, School of Social and Economic Development, Universiti Malaysia Terengganu, 21030 Kuala

Terengganu, Terengganu

Email: m.radhi@umt.edu.my

Nurul Syahirah Husin

Postgraduate Student, Faculty of Human Development, Sultan Idris Education University, 35900

Tanjong Malim, Perak, Malaysia

Email: nurulsyahirahhusin@gmail.com
\end{abstract}

\section{ABSTRACT}

This descriptive study is aimed at examining the validity and reliability of the Art Drawing House-TreePerson Module (AD-HTP) Among the Counselors in Malaysia. This module is developed based on nine (9) main AD-HTP principles: 1) There is no $100 \%$ accuracy in AD-HTP, 2) HTP method is derived from clinical psychology, 3) HTP method can be used on individuals with modest problems and healthy individuals, 4) Do not judge clients, 5) AD-HTP practitioners cannot put on any values, 6) The most accurate AD-HTP interpretation is the clients' own validation, confession and sharing, 7) AD-HTP is an intuitive therapy, 8) you determine your own choice and fate and 9) Understand AD-HTP interpretation and Cognitive-Behavioral Therapy (CBT) interventions. This module emphasizes on the concept of projective drawing techniques. Projective drawing is a technique that demonstrates one's feelings and thoughts through symbols in the form of drawings. In projective drawings, symbols illustrated such as home, tree, person and other elements are the key themes that can describe the attitudes, feelings, concerns and conflicts that one dynamically and continuously experienced. The 
INTERNATIONAL JOURNAL OF ACADEMIC RESEARCH IN BUSINESS AND SOCIAL SCIENCES Vol. 8, No. 10, Oct. 2018, E-ISSN: 2222-6990 @ 2018 HRMARS

AD-HTP module has six main strategies, namely Strategy 1: Introduction of House-Tree-Person (HTP), Nature and Human Concept and AD-HTP Related Questions, Strategy 2: General Interpretation, Specific Structure and Form of HTP, Strategy 3: Symbolic Interpretation of the House, Strategy 4: Symbolic Interpretation of the Tree, Strategy 5: Symbolic Interpretation of the Person and Strategy 6: Kinetic Interpretations of Other Symbols and Application of AD-HTP Counseling/ Guidance Sessions. To test the validity of the content, 15 expert panels composed of psychologists, counselors and educators were selected to answer the questionnaire on content validity of the module based on Russell (1974) and questionnaire on validity on session and activity based on Mohammad Aziz Shah (2010). Next, 78 respondents of the Malaysian counselors took the pilot test in order to obtain reliability value. The findings of the content validity of the module based on Russell (1974) was 0.83 (83.44\%) and the session and activity appropriateness validity value based on Mohammad Aziz Shah (2010) was 0.88 (88.26\%). The reliability value of the overall module is high which is 0.84 . The findings show that Art Drawing House-Tree-Person (AD-HTP) Modules among the Counselors in Malaysia have high content validity and reliability values and prove that the AD-HTP Module is suitable for finding talents, potentials, obstacles, problems and trauma in aspects of dreams, self-concepts, relationships and kinship.

Keywords: Content Validity, Reliability, Art Drawing House-Tree-Person (AD-HTP)

\section{INTRODUCTION}

Art Drawing House-Tree-Person (AD-HTP) Module is a very unique, easy, fast and effective technique that breaks deeply into the individual's feelings and thoughts. Anyone can master this knowledge by only looking at the children, teenagers or parents' drawings of the House, Tree and Person. We can deeply explore feelings, thoughts and traumatic experiences along with alternative psychological interventions. There are over 100 Art Drawing Project Test (HTP) published abroad but there is no practitioner in Malaysia. This course provides an opportunity for individuals to acquire knowledge and practice Art Drawing HTP effectively and with guidance. Projective drawings of House, Tree and Person are derived from clinical psychology which were developed systematically and elaborately by John Buck and Emanuel Hammer (1969). But now, its use has been widely expanded due to its effectiveness in exploring clients and guidance processes. HTP drawing symbols through pictures of House, Tree, Person and other symbols are the Sub Conscious Mind language that can describe on the attitude, talent, feelings, anxiety, conflict, and trauma experienced by an individual dynamically and continuously. Projective picture of House, Tree, and Person is very significant with human life. The House represents family interaction and relationships, the Tree describes the process of human development which includes dreams, determination and future thinking and Person is the projective of self-concept. Hopefully the art of HTP Art Drawing is growing in Malaysia, producing many practitioners and helping a lot of people. AD-HTP technique is able to enhance one's credibility in lectures, motivations, guidance, counseling and psychology sessions with its unique and effective 
methods of attracting clients. Therefore, this study aims to test the content validity and reliability of AD-HTP being developed.

\section{PROBLEM STATEMENT}

Projective drawing test or technique is a term introduced by Lawrence Frank (1939) in the book by Burns (2009), which is an application of psychoanalytic theory that was pioneered by Sigmund Freud. This technique is a psychological assessment method whereby respondents project the instincts, desires and unconscious mind to the blurry or unclear stimuli. Stimulation is an unstructured and relative (non-absolute, relative) material and respondents are required to explain, tell, complete or respond in a certain way.

The projective drawing technique is very different from a set of questionnaires or inventory that is more objective, quantitative and has measurement scale. The projective drawing technique usually use blurred, unclear and unstructured stimuli. Unstructured, relative and open stimuli provide a wider space for respondents to express perceptions without limitation by bias or investigator requirements. It is assumed that unstructured, relative and open source stimulations have greater possibility of revealing the essential aspects of one's personality and are said to be very effective in revealing hidden secrets or unconscious personality aspects over structured materials such as questionnaire and inventory.

This technique does not restrict respondents' responses and gives respondents the freedom to express what they feel and think. This also prevents respondents from giving fake answers or wanting to hide something.

Therefore, with the research being conducted to develop, to gain validity and reliability values in the Art Drawing House-Tree-Person (AD-HTP) Module among the Counselors in Malaysia, researchers are convinced that this module is able to contribute significantly to schools and institutions of higher learning students and to public and private institutions as well as to the public.

\section{RESEARCH OBJECTIVE}

The study aims to:

a. To develop of the Art Drawing House- Tree- Person (HTP) Module among the Counselors in Malaysia.

b. To obtain the content validity of the Art Drawing House-Tree-Person Module (AD-HTP) among the Counselor in Malaysia based on Russell's recommendation (1974).

c. To obtain the content validity of the Art Drawing House-Tree-Person Module (AD-HTP) among Counselors in Malaysia based on sessions and activities as suggested by Mohammad Aziz Shah (2010).

d. To obtain the overall reliability and sub-scale of Art Drawing House- Tree- Person (HTP) module among the Counselors in Malaysia.

\section{THEORETICAL APPROACH}

There are various types of projective techniques used primarily in psychological clinical therapy. Projective technique is based on the assumptions of psychoanalysis theory developed by Sigmund 
Freud. The greatest contribution of this theory is the subconscious mind. This subconscious mind is often driven by instincts termed Id. Id acts through the principle of excitement. Freud believes that understanding of this subconscious mind is very important for practitioners of psychoanalysis therapy. The popular technique for extracting the subconscious mind into the conscious mind is to use projective tests (Mornant, 1997). According to Mornant (1997), the interpretation of the drawings and the projective test began to be popular through psychoanalysis theory. The theory assumes that the interpretation of human personality aspects cannot be easily measured through reporting techniques from questionnaire or inventory. This is because the assessment is based on limited values. To get more in-depth information about the individual inner world, one needs to have the ability to explore the individual's subconscious mind and identify individual barriers and tricks of the real world. Using blurry and indirect materials such as pictures, drawings and sentence connections, individuals are free to express answers without any outside barriers.

According to psychoanalysis view, it is not the material that is the main focus but the individual's perception in responding to stimuli which actually determines the inner impulses that determine the personality traits of a person. Thus, the projective test is of the opinion that the drawing to interpret one's personality traits is considered something of a great significance. This projective drawing technique needs to be combined with other techniques in psychoanalysis therapy such as free relevance techniques, dream governance, and self-defense. All of these techniques in psychotherapy are based on one source, which is to identify the subconscious mind which is a major factor in driving of human behavior into the conscious mind of the patient or client. Emotionally hidden emotions provide an emotional relief to the client. This phase is also referred to as catharsis. To date, there are several popular projective techniques including Inkblot Test, Thematic Appreciation Test, Draw a Person, House-Tree-Person Drawing and Kinetic Family Drawing (Mornant, 1997).

The projective drawing technique was given a new lease of life by Abraham Maslow in 1954. The technique which was introduced by Freud's Psychoanalysis is more likely to see projective drawings as individual symptoms of psychological illnesses and internal emotional conflicts. Maslow's theory is more likely to see the drawings as a vision of human development and potential (Burns, 2009). Maslow is well known for the model of human development through the hierarchy of needs. This hierarchy of needs contains five stages namely the need for life such as eating, drinking, sex, and security, the need for a body such as self-acceptance and seeking self-potential, social needs such as seeking status, appreciation and power, the need for self-esteem such as affection and love and the need to achieve self-perfection such as creativity and self-recognition. All of these requirements can be seen from the sketches illustrating human needs that are yet to be achieved by humans. This picture can be interpreted according to the stages based on the hierarchy of needs (Burns, 2009).

Next, the model used in this module is Russell's content validity model (1974). Russell (1974) states that modules can be applied in all circumstances whether in individual, group, academic, nonacademic activities and these modules are capable of bringing individuals towards positive change. Russell (1974) explains that a module is considered to have a good content validity when the following five conditions are fulfilled: a) Meet the target population (taking into account the behavior of counselors and the client's character), b) The teaching situation or implementation method is good and perfect, c) The time taken to spend on the module is appropriate and adequate, d) Successfully 
improve the individual's attitude towards being more effective and e) Excellent in changing individual perceptions towards his own character.

Russell (1974) says that the most important thing in developing a module is its pilot stage. The target objectives stated in the module will either be achieved or not will be determined at this stage. During the pilot stage, the module developer will obtain various information such as spelling errors, weak sentence structure, time suitability, understanding of the activities carried out, the suitability of media tools used and the likes. All the information to be acquired is a guide to the module developer to improve and refine the module to be better and more robust. Module creators can improve their weaknesses as well as improve the quality of their modules through feedback received.

\section{RESEARCH METHODOLOGY}

The design of this study is a descriptive study which involves development analysis, content validity analysis and reliability analysis. Mohd Majid (2005) states that a descriptive study describes a situation and phenomenon. In addition, Sidek (2002) states that descriptive design is intended to provide systematic information about the facts and characteristics of a population or a field of interest factually and accurately. This study is divided into two forms of descriptive study i.e., preliminary study and survey-based study by testing the content validity and reliability of the module. This part describes a three-phase study process i.e., Phase I: Development of modules, sub modules and activities based on library research, Phase II: Testing the content validity values by experts and Phase III: Testing the reliability of the module.

\section{Phase I Study}

Phase I study is the development of modules and submodules based on nine (9) main AD-HTP principles through library research. The selection of projective drawing technique conceptual approach was made after a comprehensive library study was conducted based on the writing of books, journals and articles by Mormant (1997), Lubin (1984, 1985), Buck (1958), Hammer (1969), Helen and Ethel (1986), Derek, Aronoff and Naomi (1990), Moshe, Alan and Vicki (2002), Yvonne (2008) and Kana, Damian, Henry and Harlene (2013).

As guidance for accurate module development, books on module development and module research were also reviewed such as Russell (1974) Modular Instruction: A Guide to the Design, Selection, Utilization and Evaluation of Modular Material, Sharifah Alwiah (1981), the introduction of individual teaching with special focus on teaching modules and learning modules, Sidek and Jamaludin (2005) Module development: How to develop training modules and academic modules and so on.

\section{Phase II Study}

Content validity is a measurement tool that examines how far the module can be used. Fauzi, Jamal and Mohd Saifoul (2014) state that validity is the ability of the test tool to measure what should be measured. According to Majid (2005), Wiersma and Jurs (1990), the validity of a measuring device is said to be high if the measuring device can measure what to it need to measure. This validity is very important as a valid statement or explanation if it represents exactly the characteristics of the phenomenon being described theorized, or explained (Hammersley and Atkinson, 1995). 
Panel evaluation panel experts are selected among individuals who are experts in the field related to the research conducted by researchers. This assessment aims to assess the suitability of the items used to measure the chosen domain. Othman (2001) states that six to nine expert panel members are sufficient in evaluating the content validity of sub module and research items.

The expert verification method is divided into two parts: a) expert assessment based on Russell (1974) which contains five statements regarding the content validity of the module, and b) the validity of the suitability of the session and activities according to Mohammad Aziz Shah (2010). The validity of suitability of activities and sessions in the module is assessed using items representing sub modules whose panel of appraisers agrees with the items by selecting the agreement scale from 0 to 10 .

\section{Phase III Study}

Furthermore, the researcher carried out the process to obtain the reliability value of the Module by distributing reliability questionnaires to the respondents of the study. The questionnaire developed by this researcher consists of items based on the session and activities in the AD-HTP Module. Reliability is often referred to as a reflection of internal stability and consistency (Creswell, 2005). The basis for a good reliability value is taken from Kerlinger (1979) that a questionnaire with a value of $\alpha$ (alpha) which exceeds 0.6 at a significant level of 0.05 is a good assessment. Once this module gets the right validity value, then this module can be administered among students, teachers and civil servants. To obtain statistical data, the researcher uses SPSS to get the Alpha-Cronbach value to evaluate the reliability of the module questionnaire.

After the first phase, the second phase and the third phase, the modules are ready for use by researchers on the study group. The modules are said to be in compliance with the module development and can be used if the modules achieve the objectives of the module development and provide a good impact (Sidek, 2005).

\section{Location of the Study}

The location of the study is the place where the study is conducted. The location of the study for Phase 1 is at public libraries and universities in Malaysia. The location of the Phase II study is at the Sultan Idris Education University, public universities, the Ministry of Education Malaysia, the Ministry of Higher Education, the Ministry of Human Resources, the Ministry of Home Affairs, the Prime Minister's Department and the public departments where the validity survey of this module is distributed. The study location for Phase III is at the Sultan Idris Education University, Ministry of Education Malaysia and Ministry of Human Resources, Ministry of Home Affairs. The location of the study was based on the suitability of the respondents at the site to meet the needs of the study.

\section{Subjects of the Study}

The subjects were only involved in the second phase and the third phase of the study. The second phase of the study involved 10 expert panel appointees from psychologists, counselors and educators to evaluate the validity of Art Drawing House- Tree- Person (HTP) Module among the Counselors in Malaysia. The third phase of the subject are the counselors in Malaysia to obtain the reliability of the module. 
INTERNATIONAL JOURNAL OF ACADEMIC RESEARCH IN BUSINESS AND SOCIAL SCIENCES

Vol. 8, No. 10, Oct. 2018, E-ISSN: 2222-6990 ㄷ 2018 HRMARS

\section{Research Instruments}

There are three research instruments being used in this study: the Art Drawing House-Tree-Person (AD-HTP) Module among the Counselors in Malaysia, based on Russell (1974), the content of the Art Drawing House-Tree-Person (AD- HTP) Module among the Counselors in Malaysia based on Mohammad Aziz Shah (2010) and the reliability survey of the Art Drawing House-Tree-Person (ADHTP) Module among the Counselors in Malaysia by the researchers with six strategies covering twelve activities.

\section{RESEARCH FINDINGS}

\section{Findings of Study Phase I}

In the first phase of the study, the researchers have successfully developed modules, sub modules and activities for the Art Drawing House- Tree- Person (HTP) Module among the Counselorsin Malaysia. This module involves the development of modules and sub modules and self-directed activities which consist of six sub modules and twelve independent activities.

\section{Findings of Study Phase II}

The development of the Art Drawing House-Tree-Person (AD-HTP) Module among the Counselors in Malaysia is also like developing a questionnaire. It is assessed for its validity. To get the validity, a specific formula content is used, the total number of scores filled by the expert $(x)$ will be divided by the total score $(\mathrm{y})$ and multiplied by one hundred. A module is confirmed to have a high validity when it scores is above 70\% (Tuckman, 1978; Jamaludin, 2002; Sidek and Jamaludin, 2005). The summary of the formula is;

\section{Expert Total Score $(x)$}

$$
\mathrm{X} 100 \%=\text { Content Validity Level of Module }
$$

Total Overall Score (y)

For this study, two expert verification methods were conducted, namely; a) the overall content validity based on Russell's (1974) method which has five statements about the validity of the module and b) the sub-module validity of the session and activity based on Mohammad Aziz Shah (2010). According to Mohd. Majid (1998), the number of three expert panels is sufficient to evaluate the expert's validity of a questionnaire. While Othman (2004) states that six to nine experts are sufficient in evaluating the module and reviewing the items.

Based on external critics, the researcher selected 15 panel critics to evaluate the Art Drawing HouseTree- Person (HTP) Module among the Counselors in Malaysia. The selection of this expert panel is done because of their expertise in the field of guidance and counseling, the development of modules and deep experience as an academic expert in psychology and counseling. For this process, the researchers have provided a complete copy of the Art Drawing House-Tree-Person (AD-HTP) Module among the Counselors in Malaysia which contains the introduction of study and manual training modules which include introduction, objectives, activity instructions, formulas and relevant appendices to get expert criticism and suggestions for every module and activity being developed. The scale for this assessment is ten points i.e.; 1 (strongly disagree) to 10 (strongly agree). 
The researchers have developed a special questionnaire based on the validity of the Russell module (1974) which states that a validity assessment module should have five key points; a) meeting the target population (taking into account the subject behavior), b) the teaching situation or modules implementation method is appropriate, $c$ ) the time allocated to carry out the module is adequate, d) the module has successfully led to the increased of student's achievement in the targeted aspect, and e) the module succeeded in changing the attitude of the student towards excellence.

The expert panel evaluation based on the validity of the module by Russell (1974) is as shown in Table 1.

Table 1: Percentage of Content Validity and Expert View Evaluation of Art Drawing- House- TreePerson (AD-HTP) Module based on Russell (1974) $(n=15)$

\begin{tabular}{|c|c|c|c|}
\hline No & Statement & $\begin{array}{l}\text { Content Validity } \\
\text { Percentage (\%) }\end{array}$ & $\begin{array}{c}\text { Expert } \\
\text { Evaluation }\end{array}$ \\
\hline 1 & $\begin{array}{l}\text { The contents of the House-Tree-Person Art } \\
\text { Drawing Module (AD-HTP) among the } \\
\text { Counselors in Malaysia meet the target } \\
\text { population. }\end{array}$ & 82.34 & Accepted \\
\hline 2 & $\begin{array}{l}\text { The contents of the House-Tree-Person Art } \\
\text { Drawing Module (AD-HTP) among Counselors } \\
\text { in Malaysia can be implemented perfectly. }\end{array}$ & 79.73 & Accepted \\
\hline 3 & $\begin{array}{l}\text { The contents of the House-Tree-Person Art } \\
\text { Drawing Module (AD-HTP) among the } \\
\text { Counselors in Malaysia are in line with the time } \\
\text { allocated. }\end{array}$ & 82.83 & Accepted \\
\hline 4 & $\begin{array}{l}\text { The contents of the House-Tree-Person Art } \\
\text { Drawing Module (AD-HTP) among the } \\
\text { Counselors in Malaysia can improve the skills } \\
\text { of guidance more effectively. }\end{array}$ & 89.62 & Accepted \\
\hline 5 & $\begin{array}{l}\text { The contents of the House-Tree-Person Art } \\
\text { Drawing Module (AD-HTP) among the } \\
\text { Counselors in Malaysia can change the } \\
\text { behavior of individuals to be better. }\end{array}$ & 83.42 & Accepted \\
\hline & Overall Module & 83.44 & Accepted \\
\hline
\end{tabular}

Table 1 shows that the minimum percentage value is $79.73 \%$ for a statement that the contents of this module can be successfully implemented. The maximum percentage is $89.62 \%$ which is the statement that the contents of this module can improve the skills of guidance more effectively. Overall, the module content conforms to and corresponds to the five validity statements of the module assessed and accepted by the expert panel. Minimum and maximum indefinite validity value difference also 
INTERNATIONAL JOURNAL OF ACADEMIC RESEARCH IN BUSINESS AND SOCIAL SCIENCES

Vol. 8, No. 10, Oct. 2018, E-ISSN: 2222-6990 (c) 2018 HRMARS

indicate that in assessing the House-Tree-Person (AD-HTP) Art Drawing Module among the Counselors in Malaysia, there is no significant difference in the expert views.

The panel's evaluation findings of the validity value of the session and activities of the Art Drawing House-Tree-Person (AD-HTP) Module among the Counselors in Malaysia based on Shah (2010) was also conducted. The results of the study are as shown in Table 2.

Table 2: The value of the content validity of the House-Tree-Person (AD-HTP) Art Drawing Module activity among the Counselors in Malaysia based on expert panel evaluation according to Mohammad Aziz Shah $2010(n=15)$

\begin{tabular}{|c|c|c|c|c|}
\hline Strategy & Activity & $\begin{array}{l}\text { Total } \\
\text { Scores }\end{array}$ & $\begin{array}{c}\text { Validity } \\
\text { Percentage (\%) } \\
\end{array}$ & $\begin{array}{c}\text { Expert } \\
\text { Evaluation }\end{array}$ \\
\hline \multirow[t]{3}{*}{ Strategy 1: } & $\begin{array}{l}\text { Activity 1: } \\
\text { Introduction to HTP, the concept of nature and }\end{array}$ & 176 & 88.00 & Accepted \\
\hline & $\begin{array}{l}\text { Human and AD-HTP related questions } \\
\text { Activity 2: }\end{array}$ & & & \\
\hline & $\begin{array}{l}\text { Practical Session AD-HTP Guidance 1: } \\
\text { Introduction to HTP, the Concept of Nature and } \\
\text { Human and AD-HTP related questions }\end{array}$ & 169 & 84.56 & Accepted \\
\hline \multirow[t]{2}{*}{ Strategy 2: } & $\begin{array}{l}\text { Activity 1: } \\
\text { General Interpretation, Structure and Specific } \\
\text { Forms of HTP }\end{array}$ & 182 & 91.05 & Accepted \\
\hline & $\begin{array}{l}\text { Activity 2: } \\
\text { Practical Session AD-HTP Guidance 2: General } \\
\text { Interpretation, Structure and Specific Forms of } \\
\text { HTP }\end{array}$ & 166 & 83.09 & Accepted \\
\hline \multirow[t]{2}{*}{ Strategy 3: } & $\begin{array}{l}\text { Activity 1: } \\
\text { Home Symbolic Interpretation }\end{array}$ & 179 & 89.57 & Accepted \\
\hline & $\begin{array}{l}\text { Activity 2: } \\
\text { Practical Session AD-HTP Guidance 3: Home } \\
\text { Symbolic Interpretation }\end{array}$ & 180 & 90.02 & Accepted \\
\hline \multirow[t]{2}{*}{ Strategy 4: } & $\begin{array}{l}\text { Activity 1: } \\
\text { Tree Symbolic Interpretation }\end{array}$ & 185 & 92.51 & Accepted \\
\hline & $\begin{array}{l}\text { Activity 2: } \\
\text { Practical Session AD-HTP Guidance 4: Basic } \\
\text { Symbolic Interpretation }\end{array}$ & 177 & 88.56 & Accepted \\
\hline \multirow[t]{2}{*}{ Strategy 5: } & $\begin{array}{l}\text { Activity } 1 \text { : } \\
\text { Symbolic Interpretation of Persons }\end{array}$ & 177 & 88.54 & Accepted \\
\hline & $\begin{array}{l}\text { Activity 2: } \\
\text { Practical Session AD-HTP Guidance 5: Symbolic } \\
\text { Interpretation of Persons }\end{array}$ & 166 & 83.08 & Accepted \\
\hline Strategy 6: & Activity $1:$ & 169 & 83.01 & Accepted \\
\hline
\end{tabular}


INTERNATIONAL JOURNAL OF ACADEMIC RESEARCH IN BUSINESS AND SOCIAL SCIENCES Vol. 8, No. 10, Oct. 2018, E-ISSN: 2222-6990 @ 2018 HRMARS

\begin{tabular}{|c|c|c|c|}
\hline $\begin{array}{l}\text { Kinetic Interpretation Other Symbols } \\
\text { Activity 2: } \\
\text { Practical Session AD-HTP Guidance 6: AD-HTP } \\
\text { Guidance Session and AD-HTP Encoding System }\end{array}$ & 170 & 85.04 & Accepted \\
\hline Overall AD-HTP Module & 2116 & 88.26 & Accepted \\
\hline
\end{tabular}

Based on Table 2, the minimum percentage of the twelve activities in the six group strategies conducted is $83.01 \%$ i.e., for Strategy 6, Activity 1: Other Kinetic Interpretation Symbols. The maximum percentage is $92.51 \%$ for Strategy 4, Activity 1: Symbolic Interpretation - Tree. Hence, based on the overall analysis, the percentage value is over $70 \%$ and accepted by the experts. This means that the level of validity of the Art Drawing House-Tree-Person Module (AD-HTP) among the Counselors in Malaysia is credible and has a strong consistency. The Art Drawing House-Tree-Person (AD-HTP) Module among the Counselors in Malaysia is also believed to be in the increasingly measurable measurements of self-concept subscales.

\section{Findings of Study Phase III}

The results of the findings in Phase III are related to the reliability value of the Art Drawing HouseTree- Person (AD-HTP) Module among the Counselors in Malaysia. Russell (1974) states that testing of the reliability of a module can be seen on how far students can follow the content of the module. Sidek (2005) explains that there are two methods to test the reliability of a module i.e., through the steps in each activity and through the objective in a module. In this study, researchers have developed a questionnaire that can test the level of reliability of the module implemented on the Malaysian counselors.

After obtaining data that has been distributed to the subject, the data was analyzed using the Cronbach Alpha $(\alpha)$ analysis method using The Statistical Package for Social Sciences (SPSS). The reliability coefficients obtained through this method are also known as Cronbach Alpha reliability coefficient (Sidek, 2005). The basis for the good reliability question of a questionnaire was taken from Kerlinger (1979) that a questionnaire with a value of $\alpha$ (alpha) exceeding 0.6 at a significant level of .05 is a good assessment. This is because each step in this module's activity will determine whether the participant has mastered the objective of the module. According to Majid (2005), a measuring tool is said to be high if the measuring tool can measure what it needs to measure. The study reliability findings are as shown in Table 3. 
INTERNATIONAL JOURNAL OF ACADEMIC RESEARCH IN BUSINESS AND SOCIAL SCIENCES

Vol. 8, No. 10, Oct. 2018, E-ISSN: 2222-6990 @ 2018 HRMARS

Table 3: Reliability Coefficient Values of Art Drawing House-Tree-Person (AD-HTP) Module Activity in Malaysia $(n=78)$

\begin{tabular}{|c|c|c|c|}
\hline Strategy & Activity & $\begin{array}{l}\text { Reliability Coefficient } \\
\text { Value }\end{array}$ & Result \\
\hline \multirow[t]{2}{*}{ Strategy 1: } & $\begin{array}{l}\text { Activity 1: } \\
\text { Introduction to HTP, the concept of nature and } \\
\text { human and AD-HTP related questions } \\
\text { Activity 2: }\end{array}$ & .87 & High \\
\hline & $\begin{array}{l}\text { Practical Session AD-HTP Guidance 1: Introduction } \\
\text { to HTP, Nature and Human Nature Concepts and } \\
\text { AD-HTP related questions }\end{array}$ & .77 & Moderate High \\
\hline \multirow[t]{2}{*}{ Strategy 2: } & $\begin{array}{l}\text { Activity 1: } \\
\text { General Interpretation, Structure and Specific Forms } \\
\text { of HTP } \\
\text { Activity 2: }\end{array}$ & .83 & High \\
\hline & $\begin{array}{l}\text { Practical Session AD-HTP Guidance 2: General } \\
\text { Interpretation, Structure and Specific Forms of HTP }\end{array}$ & .79 & Moderate High \\
\hline \multirow[t]{2}{*}{ Strategy 3: } & $\begin{array}{l}\text { Activity } 1: \\
\text { Home Symbolic Interpretation } \\
\text { Activity } 2 \text { : }\end{array}$ & .83 & High \\
\hline & $\begin{array}{l}\text { Practical Session AD - HTP Guidance 3: House } \\
\text { Symbolic Interpretation }\end{array}$ & .85 & High \\
\hline \multirow[t]{2}{*}{ Strategy 4: } & $\begin{array}{l}\text { Activity } 1: \\
\text { Tree Symbolic Interpretation } \\
\text { Activity } 2 \text { : }\end{array}$ & .92 & High \\
\hline & $\begin{array}{l}\text { Practical Session AD - HTP Guidance 4: Basic } \\
\text { Symbolic Interpretation }\end{array}$ & .89 & High \\
\hline \multirow[t]{2}{*}{ Strategy 5} & $\begin{array}{l}\text { Activity 1: } \\
\text { Symbolic Interpretation of Persons }\end{array}$ & .76 & Moderate High \\
\hline & $\begin{array}{l}\text { Activity 2: } \\
\text { Practical Session AD - HTP Guide 5: Symbolic } \\
\text { Interpretation of Persons }\end{array}$ & .80 & High \\
\hline \multirow[t]{3}{*}{ Strategy 6} & $\begin{array}{l}\text { Activity 1: } \\
\text { Other Interpretation Symbols }\end{array}$ & .80 & High \\
\hline & $\begin{array}{l}\text { Activity 2: } \\
\text { Practical Session AD - HTP Guidance 6: AD-HTP } \\
\text { Guidance Session and AD-HTP Encoding System }\end{array}$ & .78 & Moderate High \\
\hline & Overall Module & .84 & High \\
\hline
\end{tabular}

Significant at values $>0.05$

Based on Table 3, the overall reliability coefficient value is high at .84. Activity 1: Principal Symbolic Interpretation in strategy 4 recorded the highest reliability value among other activities i.e., .92 and Activity 1: Symbolic Interpretation of Person recorded the lowest value in all activities of the HouseTree-Person Art Drawing Module (AD-HTP) among the Counselors in Malaysia i.e., .76 
INTERNATIONAL JOURNAL OF ACADEMIC RESEARCH IN BUSINESS AND SOCIAL SCIENCES

Vol. 8, No. 10, Oct. 2018, E-ISSN: 2222-6990 @ 2018 HRMARS

\section{DISCUSSION AND IMPLICATIONS OF STUDY}

Based on the literature review, Art Drawing House-Tree-Person Module (AD-HTP) among Counselors in Malaysia is developed with six strategies and twelve activities with two activities for each strategy. The concept of this technique is a psychological evaluation method whereby respondents project their instincts, desires, unconscious minds to vague or unclear stimuli. The projective drawing technique has given a new dimension to the interpretation of an individual's mental and personality capacity.

Cohan (2000) in his book titled Psychological testing and assessment, found that clinical psychologists and some therapists not only make their diaognosis or evaluation of the patients or clients through the inventory scoring system to assess their level of depression, maturity, and personality traits development, they also like to make interpretation through intuition based on their experience and the qualities inherent from the projective drawing technique.

Subsequently, the study obtained the content validity to make a revision in terms of accuracy of the term, language and the understanding of the module using expert views. The validity of Art Drawing House-Tree-Person (AD-HTP) Module among the Counselor in Malaysia using external criticism and adopting two opinions for verification, that is; a) Validation based on Russell validity module (1974) which has five validity statements in terms of session divisions and b) Validation based on validity assesment of the sessions and activities according to Mohammad Aziz Shah (2010). The findings of the content validity by the experts for both views found that the validity value of this module is higher than the minimum set level of $70 \%$. This proves that the developed module has high content validity in treating aspects that should be treated as in the module's objective.

The Art Drawing House-Tree-Person (AD-HTP) Module among the counselors in Malaysia has been tested for its validity in this study which can be used as the foundation in helping individuals understand the problems they face and recognizing their personalities through projective drawing techniques. Projective drawing techniques are typically used by psychotherapist to assess cognitive, intelligence, personality or emotional conflicts such as depression (Mornant, 1997).

In this study, the researcher will select the House-Tree-Person (HTP) projective drawing technique to uncover personal traits that can lead to self-concept. The interpretation of the drawing is the result of a study developed by Sigmund Freud in psychoanalysis theory. The assumption is that many important aspects of a person's personality cannot be explained and analyzed through questionnaire or inventory as this method has limited values.

Therefore, Psychoanalysis Theory explains that in order to obtain a precise view of one's inner world, the individual needs to circumvent the unconscious defence mechanism and the conscious resistance. Thus, psychoanalysis perspectives such as projective drawing techniques using indirect approaches are important (Mornant, 1997).

In addition, the implications of the study which can be concluded in this study is that this module can effectively help the counselors to thoroughly guide and deepen individual personalities in the order of the activities provided. The activities provided will help psychologists, counselors, civil servants, teachers and facilitators to master the lessons that they learned in the Art Drawing House-TreePerson Module (AD-HTP) among the Counselors in Malaysia, through active thinking, looking at the environmental context based on different perspectives and organize each idea accordingly (Sukiman Saad, 2013). 
Hence, this study can further enhance exposures on how human subconscious mind function works and the things that are hidden in the realm of reality. Through this structured module, the personality, attitudes, feelings, concerns, conflicts experienced by an individual dynamically and continuously can be critically analyzed and action plans can be made in the event of certain problems arise in the future.

The next implication is on the training that must be provided by the researcher or expert in the Art Drawing House-Tree-Person (AD-HTP) Module among the Counselors in Malaysia to train psychologists, counselors, civil servants, teachers and facilitators who wishes to carry out this module. Structured and in-depth training should be given to them in order to run this module using the correct method (Bleedorn, 1993). Training should also take priority so that psychologists, counselors, civil servants, teachers and facilitators are more creative in establishing a close relationship with their clients when implementing this module. The background of clients with different knowledge and resistance is one of the challenges for psychologists, counselors, civil servants, teachers and facilitators in handling them (Piccolo, 2008). In addition, with this module, this psychotherapy techniques can be widely develop.

\section{RECOMMENDATIONS}

Based on the study findings, some suggestions are presented that are;

1. This study can be continued in the future to determine the effectiveness of the Art Drawing House-Tree-Person (AD-HTP) Module among the Counselors in Malaysia by experimental and focused studies.

2. A future study can be implemented over a longer period of time and provides postintervention tests by conducting follow-up tests based on a specific time interval to see the change in the client's personality.

3. The results of high validity and reliability value prove on the effectiveness of these modules and psychologists, counselors, civil servants, teachers and facilitators are advised to follow this module in order to apply it to their clients in assessing personality traits, attitudes, feelings, and the conflict experienced by the clients.

\section{SUMMARY AND CONCLUSION}

Overall, this study has succeeded in developing the Art Drawing House-Tree-Person Module (AD-HTP) among the Counselors in Malaysia based on various theories and previous studies. Furthermore, the Art Drawing House-Tree-Person Module (AD-HTP) among the Counselors in Malaysia is also proven to have a high degree of content validity and reliability. This module is proven to be useful in finding talent, potential, obstacles, problems and trauma in the aspects of dreams, self concepts, relationships and kinship. Therefore, the Art Drawing House-Tree-Person (AD-HTP) Module among the Counselors in Malaysia provides psychological intervention to address all of the key aspects based on the Cognitive-Behavioral Therapy (CBT) approach. 
INTERNATIONAL JOURNAL OF ACADEMIC RESEARCH IN BUSINESS AND SOCIAL SCIENCES

Vol. 8, No. 10, Oct. 2018, E-ISSN: 2222-6990 @ 2018 HRMARS

\section{CORRESPONDING AUTHOR}

Associate Professor Dr Mohammad Aziz Shah Mohamed Arip

Sultan Idris Education University, Malaysia

Email: aziz.shah@fpm.upsi.edu.my

Falculty of Human Development, Sultan Idris Education University 35900 Tanjong Malim, Perak

\section{Reference}

Ahmad, J. (2002). The Validity, Reliability and Effectiveness of the Self-Improved Program Module On The Motivation of Achievement Among Students in Selangor State Secondary School. PhD thesis, Universiti Putra Malaysia.

Alsagoff, S. A. (1981). Introduction to teaching with special focus on teaching modules and learning modules.

Bleedorn, B. D. (1993). Introduction: Toward an integration of creative and critical thinking.

Buck, J.N. (1981). The House-Tree-Person Technique-Revised Of The Human Figure. Springfield: Charles C. Thomas.

Buck, J. N. (1948). The H-T-P technique, a qualitative and quantitative scoring manual.. Journal of Clinical Psychology, 4 (Monogr. Suppl. 5)

Buck, J. N. (1950). Richmond workshop materials on the House-Tree-Person (H-T-P), Beverly Hills, Ca.: Western Psychological Services.

Buck, J. N., \& Hammer, E. F. (Eds.). (1969). Advances in the house-tree-person technique: Variations and applications. Los Angeles: Western Psychological Services.

Buck, J. N. (1964). The House-Tree-Person (H-T-P) Manual Supplement, Los Angeles: Western Psychological Services.

Buck, J. N. (1966). The House-Tree-Person Technique, Revised Manual, Los Angeles: Western Psychological Services.

Burns, R.C. (2009). Kinetic-House-Tree-Person Drawing (K-H-T-P) An Interpretative Manual. New York: Routledge.

Burns, R.C (1972). Actions, styles and symbols in kinetic family drawings (K-F-D); An interpretative manual . New York: Routledge.

Cohan, R. J \& Mark, E. S. (2000). Psychological testing and assessment. Singapore: McGraw-Hill.

Creswell, J. W. (2005). Educational research: Planning, conducting and evaluating quantitative and qualitative research. Upper Saddle River, New Jersey: Pearson Education, Inc

Derek, N.A. \& Naomi, B. M. (1990). Sex, Sex Role Identification, And College Students' Projective Drawings. Journal of Clinical Psychology, 46 (4), 460-466.

Frank, L. K. (1939). Projective methods for the study of personality. The Journal of psychology, 8(2), 389-413.

Freud, S. (2013). The interpretation of dreams. Read Books Ltd.

Hammer, M., \& Kaplan, A. M. (1966). The reliability of children's human figure drawings. Journal of Clinical Psychology, 22(3), 316-319.

Hammersley, M., \& Atkinson, P. (1995). Ethnography: Practices and principles. New York: Routledge. Retrieved December, 2, 2008. 
INTERNATIONAL JOURNAL OF ACADEMIC RESEARCH IN BUSINESS AND SOCIAL SCIENCES

Vol. 8, No. 10, Oct. 2018, E-ISSN: 2222-6990 @ 2018 HRMARS

Hussin, F., Ali, J., \& Noor, M. S. Z. (2014). SPSS data research \& analysis method. Universiti Utara Malaysia Press.

Imuta, K., Scarf, D., Pharo, H., \& Hayne, H. (2013). Drawing a close to the use of human figure drawings as a projective measure of intelligence. PloS one, 8(3), e58991.

Jusoh, A. J., Isa, N. J. M., \& Razali, M. M. S. M. (2015). Problem-Based Learning: Mandatory Personal Qualities of Effective Facilitators. International Journal of Learning, Teaching and Educational Research, 13(2).

Kerlinger, F.N. (1979). Behavioral Research: A Conceptual Approach. New York: Holt, Rinehart, and Winston.

Lubin, B., Larsen, R. M., Matarazzo, J. D., \& Seever, M. (1985). Psychological test usage patterns in five professional settings. American Psychologist, 40(7), 857.

LePine, J. A., Piccolo, R. F., Jackson, C. L., Mathieu, J. E., \& Saul, J. R. (2008). A meta-analysis of teamwork processes: tests of a multidimensional model and relationships with team effectiveness criteria. Personnel Psychology, 61(2), 273-307.

Lepore, E., \& Smith, B. C. (2006). The oxford handbook of the philosophy of language.

Arip, M. A. S. (2008). Successful motivational counseling to the university: Modules and self-directed activities create success for the university. Tanjong Malim: Publisher of Universiti Pendidikan Sultan Idris.

Maslow, A. H. (1954). Personality and motivation. Harlow, England: Longman, 1, 987.

Konting, M. M. (2005). Educational Research Methods. Kuala Lumpur: Dewan Bahasa dan Pustaka.

Mornant, G.G. (1997). Handbook of psychological assessment ( $3^{\text {rd }}$ ed.). USA: John Wiley \& Son, Inc.

Othman Mohamed (2001). Thesis Writing in Applied Social Science. Serdang: Publisher Universiti Putra Malaysia.

Polatajko, H., \& Kaiserman, E. (1986). House-Tree-Person projective technique: a validation of its use in occupational therapy. Canadian Journal of Occupational Therapy, 53(4), 197-207.

Russell, J. D. (1974). Modular Instruction: A Guide to the Design, Selection, Utilization and Evaluation of Modular Materials. New York: Publishing Company.

Torem, M. S., Gilbertson, A., \& Light, V. (1990). Indications of physical, sexual, and verbal victimization in projective tree drawings. Journal of clinical psychology, 46(6), 900-906.

Tuckman, B. W., \& Harper, B. E. (2012). Conducting educational research. Rowman \& Littlefield Publishers.

Wiersma, W. \& Jurs, S. G. (1990). Educational Measurement and Testing. $2^{\text {nd }}$ Edition. Needham Heights, MA: Allyin and Bacon.

Yvonne, P. (2008). The Use of Projective Drawings to Determine Visual Themes in Young Kuwaiti Women Impacted by the Iraqi Invasion. Journal compilation NSEAD, 27 70-81. 